The Israeli Journal of Aquaculture - Bamidgeh, IJA_69.2017.1429, 8 pages

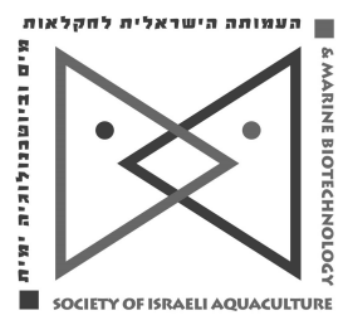

The IJA appears exclusively as a peer-reviewed on-line open-access journal at http://www.siamb.org.il/. To read papers free of charge, please register online at registration form.

Sale of IJA papers is strictly forbidden.

\title{
Polyculture of Sea Cucumber Holothuria scabra with Pacific White Shrimp Litopenaeus vannamei
}

\author{
Song Jiang ${ }^{1,2}$, Falin Zhou ${ }^{1}, 2 *$, Xianbin Mo ${ }^{3}$ Jianhua Huang ${ }^{1,2}$, Qibin \\ Yang ${ }^{1,2}$,Lishi Yang ${ }^{1,2}$
}

1 The South China Sea Fisheries Research Institute, Chinese Academy of Fishery Sciences, Guangzhou,510300, P.R. China

${ }^{2}$ Key Laboratory of South China Sea Fishery Resources Exploitation \& Utilization,

Ministry of Agriculture, Guangzhou Guangdong 510300, P.R.China

3 College of Fisheries, Henan Normal University, Xinxiang,453007, P.R.

China

Keywords: Holothuria scabra; Litopenaeus vannamei; PS; sediment; bioremediation

\begin{abstract}
An experimental study of polyculture of sea cucumber Holothuria scabra with Pacific white shrimp Litopenaeus vannamei was carried out in the laboratory. Results indicated that nutrient structure of the culture system was influenced significantly by the sea cucumber: the phosphate and nitrate concentrations were enhanced more obviously in the polyculture system (PS) than in the monoculture system (MS), but by contrast, the ammonium concentration remained low in the PS. The sulfide contents of the sediment were reduced in the PS to $10.32 \pm 1.85 \mathrm{mg} / \mathrm{kg}$, accounting for about $2 / 5$ of that in the MS. The PS of sea cucumbers had positive effects on the growth and survival of shrimp, the specific growth rate of weight of shrimp in the PS was $2.89 \pm 0.63 \%$ /day and significantly higher than that of the MS (average $2.05 \pm 0.57 \% / d$ ). Survival rate of the shrimp in PS was $79.3 \pm 22.9 \%$, dramatically higher than that of the MS (average $64.0 \pm 17.5 \%$ ). In the PS, the shrimp had no negative effect on the sea cucumbers who ingested and assimilated food residue in the sediment of the culture system with an assimilation efficiency of $42.06 \pm 10.62 \%$ for organic matter. PS of sea cucumber Holothuria scabra in the shrimp culture system had both environmental and economic benefits. This PS method could contribute to sustainable development of aquaculture in China.
\end{abstract}

\footnotetext{
* Corresponding author. Tel.: +86-20-84451346; E-mail address: zhoufalin@aliyun.com
} 


\section{Introduction}

Shrimp culture is one of the pillar industries to promote the development of China's coastal economy (Tang et al., 2014). With the increasing scale of shrimp farming, the problem of environmental pollution caused by feed remnants and excrement in shrimp culture is prominent (Liu et al., 2008). Effective control of shrimp culture in the field of aquaculture and achievement of "clean production" has become a problem to be solved by scientific research.

Sea cucumber is a typical animal that filters sediment in water bodies and can consume considerable amounts of organic matter, bacteria, debris particles, and dead organisms (Kang et al., 2003; Bruckner et al., 2005). In recent years, environmental regulation and the control function of sea cucumbers has been widely valued by researchers at home and abroad (Chen et al., 2004; Mercier et al., 2000; Dong et al., 2006; Asha et al., 2005). Research shows that the sediment of shrimp culture contains many nutrients, which can provide a good food source for sea cucumbers, and that PS of sea cucumber with shrimp can not only regulate the aquaculture environment, but also bring considerable economic benefits at the same time (Purcell et al., 2006; He et al., 2008). In China, research and practice of shrimp and sea cucumber PS is concentrated mainly in northern coastal China at present; the species of sea cucumbers for PS is Apostichopus japonicus (He et al., 2008). However, the southern coastal region of China is the main shrimp-farming area. Water temperatures can reach over $25^{\circ} \mathrm{C}$ for most the year which is not suitable for $A$. japonicus culture. Some economic tropical sea cucumber species, such as Stichopus variegates are on the verge of extinction. Therefore, it is necessary to find an adaptable tropical species of sea cucumbers to ensure successful implementation of their culture.

Holothuria scabra is a commercially harvested holothurian found throughout the Indo-Pacific from the Red Sea and East coast of Africa to Japan and Cook Islands (Conand, et al., 1986; Conand, et al., 1993; Battaglene, et al., 1999; ). Research has shown that Holothuria scabra has a choice feeding ability of the sediment at the bottom of the sea. It plays the role of cleaner and scavenger of seabeds (Bonham, et al., 1963; Dzeroski,et al., 2003; ). In addition, $H$. scabra is able to survive in high temperature environment of above $38^{\circ} \mathrm{C}$; it also has a wide salt tolerance, ranging from salinity of $18-38$, and survival rate can reach to $100 \%$. It shows a strong ability to feed in that environment (Yu, et al., 2012). The biological characteristics, distribution, and economic value of $H$. scabra suggests that this kind of sea cucumber can be used as the restorer of the shrimp culture environment. However, there are no reports of PS of Holothuria scabra with Litopenaeus vannamei. In this paper, we put forward the idea of regulating the shrimp culture environment with $H$. scabra, and explore the effect of PS of $L$. vannamei with $H$. scabra in indoor conditions to provide a scientific basis for the optimization of a shrimp culture environment and the proliferation and culture of tropical sea cucumber in south China.

\section{Materials and Methods}

Experimental animals. The PS study of $L$. vannamei with $H$. scabra was conducted at the Shenzhen Base of South China Sea Fisheries Research Institute of CAFS (Shenzhen China) in May 2016. The $H$. sca was collected from the sea near the Shenzhen Base and the $L$. vannamei was obtained from the farm of Shenzhen Base. Prior to the trial, the animals were acclimated in a pond for 1 week. Continuous aeration was provided, and a small amount of sea mud was fed to the sea cucumbers. A shrimp diet $(45.4 \%$ crude protein, $9.3 \%$ crude lipid and $10.6 \%$ ash) was fed to the shrimps during this acclimation period. The sea cucumbers of uniform size and health with an average wet weight of $42.43 \pm 3.21 \mathrm{~g}$ and shrimp of uniform size and health body with an average body length of $8.65 \pm 0.29 \mathrm{~cm}$ and wet weight of $5.31 \pm 0.57 \mathrm{~g}$ were selected for the PS experiment.

Aquaculture facilities and seawater. The PS experiment system included 10 identical square cement ponds $\left(1 \mathrm{~m}^{*} 1 \mathrm{~m} * 1 \mathrm{~m}\right)$ with sandy sediment of $5 \mathrm{~cm}$ thickness. The sediment was collected from a seabed near the Shenzhen Base, dried, and ground through a 10mesh screen to make sure that the particle sizes were edible for the sea cucumbers. $75 \%$ of cement ponds were covered with opaque canvas to reduce light interference. The seawater (27.9-31. $1^{\circ} \mathrm{C}$, salinity from $29.2-31.8 \mathrm{psu}, \mathrm{pH}$ from 7.9-8.3) was extracted from the adjacent sea area and sieved through a $5 \mu \mathrm{m}$ filter bag. Nitrate (NO3-N) was too low 
to detect. Nitrite (NO2-N) and ammonia nitrogen( $\mathrm{NH} 4-\mathrm{N})$ ranged from $0.52-0.73 \mu \mathrm{mol} / \mathrm{L}$ and $5.40-5.73 \mu \mathrm{mol} / \mathrm{L}$ respectively.

Experimental design. A total number of 600 shrimp were randomly assigned to 10 cement ponds from Pond 1 to Pond 10 with 60 individuals in each pond. The experiment included two treatments a) monoculture (control group) and b) PS. 60 prawns and 7 sea cucumbers were kept in each experimental cement pond. 60 prawns only, were stocked in the control group. There were 5 replicates in each treatment. The experiment lasted from May 1st, 2016 to June 25th, 2016, a total of 56 days. The shrimp were fed a commercial diet at 09:00 and 17:00 at a rate of $8 \%$ body weight per day. The feeding ration was flexible and adjusted according to the shrimp feeding conditions. During the study period, water was changed at a rate of $30 \%$ every day. The water and sediment quality of each pond were monitored on day 1,14, 28, and 56 before the water exchange. During the experiment, continuous aeration was supplied. Survival of the animals was inspected every day and the dead individuals were timely removed. At the end of the experiment, the survival rate (SR; \%) and the specific growth rates (SGR;\% / d) of shrimp and sea cucumber were recorded,

$$
\begin{aligned}
& \mathrm{SR}=100 \times \mathrm{X}_{2} / \mathrm{X}_{1} \\
& \mathrm{SGR}=100 \times\left(\operatorname{LnY}_{2}-\operatorname{LnY}_{1}\right) / \mathrm{t}
\end{aligned}
$$

Where $X_{1}$ (ind) is the initial number of cultured animals that were stocked, and $X_{2}$ (ind) is the final number of cultured animals. $Y_{1}(g$ or $\mathrm{cm})$ is the initial wet weight or length of cultured animals, and $Y_{2}(\mathrm{~g}$ or $\mathrm{cm})$ is the final wet weight or length of cultured animals and $t$ is the duration of the experiment.

Ingestion and assimilation. Five sea cucumbers were randomly collected after the PS experiment. The Holothuria scabra ingestion and assimilation experiment was conducted in 5 aquariums $(30 \mathrm{~cm} \times 20 \mathrm{~cm} \times 30 \mathrm{~cm})$ for 3 days. Five sea cucumbers were randomly collected and stochastically assigned to 5 aquariums after the PS experiment. The sea cucumbers were weighed before they were assigned to the aquariums. The sediment of $5 \mathrm{~cm}$ was placed at the bottom of the aquariums. All aquariums were covered with opaque canvas in order to reduce light interference. The feces of each sea cucumber were collected at 8:00 and 18:00 daily. The feces collected on the first day were discarded, and the ones collected on the remaining 2 days were combined and rinsed with deionized water to remove the salt. The feces were then dried at $60^{\circ} \mathrm{C}$ to determine the inorganic content. The experiment was conducted without water changes. The dissolved oxygen was higher than $6.5 \mathrm{mg} / \mathrm{L}$. Since sea cucumbers cannot digest inorganic minerals in the sediment, the ingestion rate (IR) was calculated according to the sea cucumber defecation rate (DR). Thus, the inorganic excrement was used as an inert tracer to calculate the ingestion rate (Yu, et al., 2012) according to the following equations:

$$
\begin{aligned}
& \mathrm{IR}=\mathrm{DR} \times \mathrm{IM}_{\mathrm{f}} / \mathrm{IM}_{\mathrm{s}} \\
& \mathrm{DR}=\mathrm{D} /(\mathrm{W} \times \mathrm{t})
\end{aligned}
$$

Where IR is the ingestion rate of Holothuria scabra $\left[\mathrm{g} /\left(\mathrm{g}^{\cdot d}\right)\right]$, DR is the defecation rate of Holothuria scabra $\left[\mathrm{g} /\left(\mathrm{g}^{\cdot d}\right)\right]$, and $\mathrm{IM}_{\mathrm{f}}$ is the content of inorganic matter in feces (\%), IMs is the content of inorganic matter in food (\%), D is the dry weight of the feces $(\mathrm{g}), \mathrm{W}$ is the wet weight of Holothuria scabra ( $g$ ) and $t$ is the duration of the experiment.

After the ingestion experiment, all the sea cucumbers were dissected to collect the contents from the foregut and hindgut. The contents were rinsed with deionized water to wash away the mucus and salt, then the contents were dried. The assimilation rate (AE) was calculated according to the difference of organic matter in the foregut and hindgut (Paltzat, et al., 2008) according to the following equation:

$\mathrm{AE}=100 \times(\mathrm{F}-\mathrm{E}) /[(1-\mathrm{E}) \times \mathrm{F}]$

Where $A E$ is the organic matter assimilation rate (\%) of sediment of the sea cucumber; $\mathrm{F}$ is the content of organic matter in foregut of sea cucumber (\%); $\mathrm{E}$ is the content of organic matter in hindgut of sea cucumber (\%).

Respiration and excretion. Five other sea cucumbers and fifteen prawns were randomly collected at the end of the PS experiment. At the beginning of the respiration and excretion trial, the sea cucumbers were starved for $24 \mathrm{~h}$, weighed, and randomly allocated to five brown $3 \mathrm{~L}$ bottles. The respiration and excretion trial of the prawns was conducted similarly 
with three prawns in each bottle. All the brown bottles were filled with fresh sea water, partly covered to enable the discharge of air bubbles. The control consisted of another 3 brown bottles without cucumbers or prawns, filled with fresh sea water. After $2 h$, the bottles were shaken to mix the sea water and the dissolved oxygen. The nutrients and salt concentration in each bottle were determined. The oxygen consumption rate (OR, $\left.\mathrm{mgO}_{2} /\left(\mathrm{g}^{\cdot h}\right)\right)$ and excretion rate $\left(E R, \mu \mathrm{M} /\left(\mathrm{g}^{\cdot h}\right)\right)$ were calculated by the following formula ( $\mathrm{Yu}$, et al., 2012):

$$
\begin{aligned}
& \mathrm{OR}=\left(\mathrm{C}_{0}-\mathrm{C}_{\mathrm{t}}\right)\left(\mathrm{V}_{\mathrm{j}}-\mathrm{V}_{\mathrm{a}}\right) /(\mathrm{W} \times \mathrm{t}) \\
& \mathrm{ER}=\left(\mathrm{C}_{\mathrm{t}}-\mathrm{C}_{0}\right)\left(\mathrm{V}_{\mathrm{j}}-\mathrm{V}_{\mathrm{a}}\right) /(\mathrm{W} \times \mathrm{t})
\end{aligned}
$$

Where $\mathrm{C}_{0}$ is the concentration of dissolved oxygen $\left(\mathrm{mgO}_{2} / \mathrm{L}\right)$ or nutrients $(\mu \mathrm{mol} / \mathrm{L})$ in the control group at the end of the experiment, $\mathrm{C}_{\mathrm{t}}$ represents the concentration of dissolved oxygen $\left(\mathrm{mgO}_{2} / \mathrm{L}\right)$ or nutrients $(\mu \mathrm{mol} / \mathrm{L})$ in the test group at the end of the experiment; $\mathrm{Vj}$ represents the volume of the brown bottles ( $L$ ) and $V a(L)$ represents the volume of the experimental animals; $W$ is the wet weight of the experimental animals $(g)$ and $t$ the duration of the experiment.

Determination of environmental factors. The water quality including water temperature $\left({ }^{\circ} \mathrm{C}\right)$, salinity, $\mathrm{pH}$, dissolved oxygen $(\mathrm{DO} ; \mathrm{mg} / \mathrm{L})$, were measured with the multi-parameter measuring instrument (YSI 6920); the concentration of nitrate $\left(\mathrm{NO}_{3}-\mathrm{N}\right.$, $\mu \mathrm{mol} / \mathrm{L})$, nitrite $\left(\mathrm{NO}_{2}-\mathrm{N} \mu \mathrm{mol} / \mathrm{L}\right)$, ammonia nitrogen $\left(\mathrm{NH}_{4}-\mathrm{N}, \mu \mathrm{mol} / \mathrm{L}\right)$ and phosphate $\left(\mathrm{PO}_{4}-\right.$ $\mathrm{P}, \mu \mathrm{mol} / \mathrm{L})$ in sea water were measured by the specification for marine monitoring (AQSIQ, 2007); the contents of sulfide $\left(\mathrm{S}^{2-} \mathrm{mg} / \mathrm{kg}\right)$ in sediment was determined by ion selective electrode method; the sediment was dried, and the content of organic matter $(\mathrm{OM}, \%)$ in the sediment was determined by ashing method (Yu, et al., 2011).

Statistical analysis. The data were analyzed using SPSS 17.0 for Windows software. One-way ANOVA was used to compare the differences of data between the different periods in the group and the difference of data between groups in the same period was compared by t-test. Percentage data were analyzed by square root sine transformation, and the results were shown as the original data. $\mathrm{P}<0.05$ represented significant difference in the data.

\section{Results}

Physical and chemical characteristics of water environment. During the experiment, the water temperature varied from $27.6-31.2^{\circ} \mathrm{C}$, salinity varied from $29.2-31.8, \mathrm{pH}$ varied from 7.9-8.3, the dissolved oxygen was saturated or nearly saturated, and there were no significant difference between the data in the same period. The nutrient structure of each group is shown in Table 1, the nutrient concentrations of all groups increased significantly with time $(\mathrm{P}<0.05)$, and reached the highest value at the end of the experiment. The concentration of nitrate $\mathrm{NO}_{3}-\mathrm{N}$ ) in the PS group was significantly higher than that in the control group $(P<0.05)$. From the beginning of the experiment the concentrations of phosphate $\left(\mathrm{PO}_{4}-\mathrm{P}\right)$ in the PS group were significantly higher than those of the control group $(\mathrm{P}<0.05)$ from the $28^{\text {th }}$ day of the experiment; the concentration of nitrite $\left(\mathrm{NO}_{2}-\mathrm{N}\right)$ in each group was not significant $(P>0.05)$ in the same period and the concentrations of $\mathrm{NH}_{4}-\mathrm{N}$ in the PS groups were significantly lower than in the control group $(P<0.05)$ from the $28^{\text {th }}$ day on of the experiment.

Table 1. Variations of the nutrient structures among treatments at different sampling time

\begin{tabular}{llllll}
\hline Index & Group & $O D$ & $14 D$ & $28 D$ & $56 D$ \\
$\mathrm{NO}_{3}-\mathrm{N}(\mu \mathrm{mol} / \mathrm{L})$ & Control & $0^{\mathrm{a}}$ & $4.58 \pm 0.53^{\mathrm{b} *}$ & $7.16 \pm 0.65^{\mathrm{c} *}$ & $10.24 \pm 1.45^{\mathrm{d}^{*}}$ \\
& PS & $0^{\mathrm{a}}$ & $10.83 \pm 0.47^{\mathrm{b}}$ & $12.42 \pm 1.25^{\mathrm{c}}$ & $16.31 \pm 2.52^{\mathrm{d}}$ \\
$\mathrm{NO}_{2}-\mathrm{N}(\mu \mathrm{mol} / \mathrm{L})$ & Control & $0.56 \pm 0.13^{\mathrm{a}}$ & $2.33 \pm 0.39^{\mathrm{b}}$ & $9.48 \pm 0.85^{\mathrm{c}}$ & $12.35 \pm 1.66^{\mathrm{d}}$ \\
& PS & $0.56 \pm 0.13^{\mathrm{a}}$ & $2.98 \pm 0.19^{\mathrm{b}}$ & $9.23 \pm 0.68^{\mathrm{c}}$ & $11.85 \pm 1.73^{\mathrm{d}}$ \\
$\mathrm{NH}_{4}-\mathrm{N}(\mu \mathrm{mol} / \mathrm{L})$ & Control & $5.41 \pm 0.25^{\mathrm{a}}$ & $16.76 \pm 1.03^{\mathrm{b}}$ & $30.48 \pm 3.26^{\mathrm{c}}$ & $36.48 \pm 3.64^{\mathrm{d}}$ \\
& PS & $5.41 \pm 0.25^{\mathrm{a}}$ & $14.33 \pm 0.72^{\mathrm{b}}$ & $20.15 \pm 2.77^{\mathrm{c}^{*}}$ & $29.75 \pm 2.34^{\mathrm{d}^{*}}$ \\
$\mathrm{PO}_{4}-\mathrm{P}(\mu \mathrm{mol} / \mathrm{L})$ & Control & $0.56 \pm 0.05^{\mathrm{a}}$ & $1.26 \pm 0.15^{\mathrm{b}}$ & $1.48 \pm 0.17^{\mathrm{b}}$ & $1.82 \pm 0.27^{\mathrm{c}^{*}}$ \\
& PS & $0.56 \pm 0.05^{\mathrm{a}}$ & $1.28 \pm 0.05^{\mathrm{b}}$ & $1.85 \pm 0.15^{\mathrm{c}}$ & $1.94 \pm 0.41^{\mathrm{c}}$ \\
\hline
\end{tabular}

All values are presented as means \pm SD. Different superscript letters indicate significant differences among sampling times within each treatment. *represents significant differences between the data of the two treatments at each sampling time.

Sediment environment characteristics. The content of organic matter (OM) and sulfur $\left(\mathrm{S}^{2-}\right)$ in sediments was significantly higher in relation to time $(P<0.05)$, and the 
concentration of $\mathrm{OM}$ and $\mathrm{S}^{2-}$ in the control groups was significantly higher $(\mathrm{P}<0.05)$ than in the PS groups. The $\mathrm{S}^{2-}$ concentration of sediment in the PS groups was $10.32 \pm 1.85 \mathrm{mg} / \mathrm{kg}$ at the end of the experiment, which was $40.27 \%$ of the $\mathrm{S}^{2-}$ concentration in the control groups at the same period and approximately equal to the $\mathrm{S}^{2-}$ concentration in the control groups at the $14^{\text {th }}$ day. The results showed that sea cucumber effectively inhibited the formation of sulfides in PS the system (Table 2).

Table 2. Variations of the sediment characteristics among treatments at different sampling time

\begin{tabular}{llllll}
\hline Index & Group & $O D$ & $14 D$ & $28 D$ & $56 D$ \\
\hline \multirow{2}{*}{$\mathrm{OM} / \%$} & Control & $0.48 \pm 0.03^{\mathrm{a}}$ & $0.76 \pm 0.06^{\mathrm{b}}$ & $0.98 \pm 0.13^{\mathrm{c}}$ & $1.36 \pm 0.22^{\mathrm{d}}$ \\
& PS & $0.48 \pm 0.03^{\mathrm{a}}$ & $0.60 \pm 0.09^{\mathrm{b}^{*}}$ & $0.84 \pm 0.12^{\mathrm{c}^{*}}$ & $1.20 \pm 0.27^{\mathrm{d}^{*}}$ \\
$\mathrm{~S}^{2-}(\mathrm{mg} / \mathrm{kg})$ & Control & $0^{\mathrm{a}}$ & $10.05 \pm 0.97^{\mathrm{b}}$ & $18.74 \pm 1.43^{\mathrm{c}}$ & $25.63 \pm 3.67^{\mathrm{d}}$ \\
& PS & $0^{\mathrm{a}}$ & $4.35 \pm 0.67^{\mathrm{b}}$ & $7.18 \pm 1.01^{\mathrm{c}^{*}}$ & $10.32 \pm 1.85^{\mathrm{d}^{*}}$ \\
\hline
\end{tabular}

All values are presented as means \pm SD. Different superscript letters indicate significant differences among sampling times within each treatment. *represents significant differences between the data of the two treatments at each sampling time.

Growth and survival. The body length specific growth rate (SGR) of the shrimp in the control group was $0.65 \pm 0.07 \% / d$ and $0.89 \pm 0.13 \% / d$ in the PS group, and the SGR in the PS group was significantly higher than that in the control group $(P<0.05)$. The body weight SGR of the shrimp in the control group was $2.05 \pm 0.57 \% / d$ and $2.89 \pm 0.63 \% / d$ in the PS group (Figure 1), and the body weight SGR in the PS group was not statistically significant $(P>0.05)$. At the end of the experiment, the survival rate (SR) of the shrimp in the PS group was $79.3 \pm 22.9 \%$, which was significantly higher than that of the control group $(64.0 \pm 17.5 \%, \mathrm{P}<0.05)$. The SR of the sea cucumbers in all groups was $100 \%$, and the SGR of body weight was $0.38 \pm 0.19 \% / d$.

घmonoculture $\square$ Polyculture
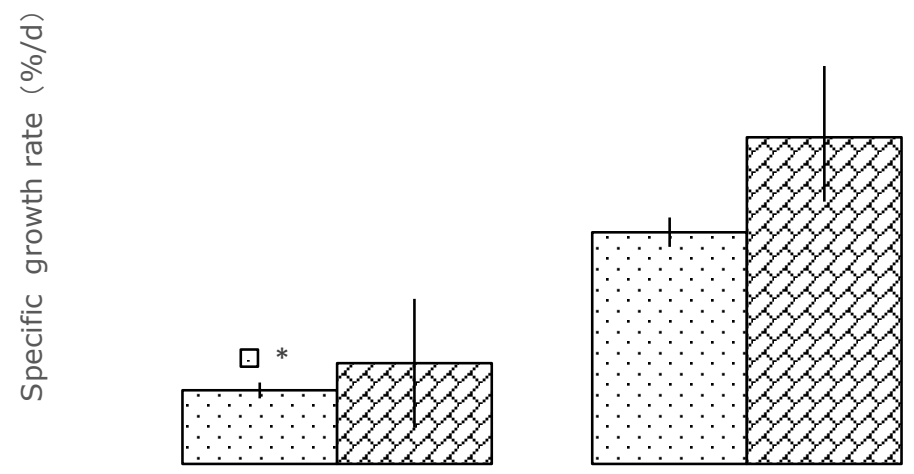

Fig.1 Growth performance of the cultured shrimp

* represents significant differences $(P<0.05)$.

Ingestion and assimilation. The sediment ingestion rate of Holothuria scabra was $0.06 \pm 0.02 \mathrm{~g} /\left(\mathrm{g}^{\cdot d}\right)$. The assimilation rate of organic matter in sediment was $40.26 \pm 10.62 \%$, and the organic matter content of the foregut was $3.17 \pm 0.31 \%$, which was close to 4.7 times that of the sediment organic matter content in the experiments.

Respiration and excretion. The oxygen consumption rate of shrimp was $0.422 \pm 0.032$ $\mathrm{mgO}_{2} /\left(\mathrm{g}^{\text {hh }}\right)$, and the oxygen consumption rate of sea cucumber was $0.015 \pm 0.002 \mathrm{mg}$ $\mathrm{O}_{2} /\left(\mathrm{g}^{\mathrm{h}}\right)$ (Table 3 ). The main form of discharging nitrogen of shrimp and sea cucumber was ammonia nitrogen and the excretion rate of shrimp and sea cucumber were $13.630 \pm 0.385 \mu \mathrm{M} /\left(\mathrm{g}^{\cdot h}\right)$ and $16.452 \pm 0.315 \mu \mathrm{M} /\left(\mathrm{g}^{\mathrm{h}}\right)$. In addition, the sea cucumber discharged a small amount of nitrite and nitrate, respectively accounted for only $0.39 \%$ 
and $2.94 \%$ of the total nitrogen discharge. The phosphate excretion rate of the shrimp was $(0.035 \pm 0.014) \mu \mathrm{M} /\left(\mathrm{g}^{\cdot h}\right)$, which was twice as much as that of the sea cucumber.

Table 3. Respiration and excretion rates of the shrimp and sea cucumber

\begin{tabular}{|c|c|c|c|c|c|}
\hline \multirow{2}{*}{ Group } & \multirow{2}{*}{$\begin{array}{l}\text { Respiration } \\
\text { rate/[mgO } /(g \cdot h)]\end{array}$} & \multicolumn{4}{|c|}{ Excretion rate $/[\mu M /(g \cdot h)]$} \\
\hline & & $\mathrm{NH}_{4}-\mathrm{N}$ & $\mathrm{NO}_{2}-\mathrm{N}$ & $\mathrm{NO}_{3}-\mathrm{N}$ & $\mathrm{PO}_{4}-\mathrm{P}$ \\
\hline Shrimp & $0.422 \pm 0.032$ & $13.630 \pm 0.385$ & - & - & $0.035 \pm 0.014$ \\
\hline Sea cucumber & $0.015 \pm 0.002$ & $16.452 \pm 0.315$ & $0.067 \pm 0.005$ & $0.501 \pm 0.004$ & $0.016 \pm 0.004$ \\
\hline
\end{tabular}

\section{Discussion}

By feeding, sea cucumber can remove residual feed and feces which are a result of mariculture, thereby reducing the pollutant content in the water system; the sea cucumber also disturbs the sediment through burial, which can have a positive effect on the stability of the diversity of benthic ecological environment and nutrient circulation (Kang, et al., 2003; Purcell, et al., 2006; Paltzat, et al., 2008; Uthicke, et al., 2001a; Uthicke, et al., 2001b; Liu, et al., 2006). At present, local and international researchers have studied the remediation effects of Apostichopus japonicus Parastichopus californicus and Stichopus mollis on the culture environment(Kang, et al., 2003; Yuan, et al., 2008; Maxwell, et al., 2009; Yang, et al., 2000), while there have been few studies on other types of sea cucumbers. Holothuria scabra is a economically valuable tropical sea cucumber. At present, the study of this sea cucumber mainly involves behavior ecology (Bonham, et al., 1963; Drumm, et al., 1999) and reproductive biology (Hu, et al., 2013). Aquacultural environment regulation has not been applied to Holothuria scabra. Results have shown that the nutrient content of shrimp improved with the addition of Holothuria scabra, and the organic matter content and sulfide in the sediments were effectively reduced. The PS of sea cucumber had a positive effect on growth and survival of shrimp.

Water nutrient structure. The total concentration of nitrogen and phosphorus in the PS group was higher than that in the MS group, due to the higher biomass of the shrimp and sea cucumbers. Although the feeding and burrowing of the sea cucumbers disturbed the sediment it also promoted the release of nutrients from the sediment into the water (Yuan, et al., 2008; Uthicke, et al., 2001a; Uthicke, et al., 2001b). During the process of shrimp culture, ammonia nitrogen came from two sources: (1) biological metabolism; (2) residual feed and fecal decomposition. The main metabolite of shrimp and sea cucumber was ammonia nitrogen. Therefore, the total amount of ammonia nitrogen excreted in the PS group was higher than that of the control group. The feeding and assimilation of the sea cucumbers effectively removed feed surplus and feces, and the nitrogen was integrated in the sea cucumber biomass. The effect of bio-disturbance also increased the oxygen flux between the sediment and the water interface and accelerated the oxidation of ammonia nitrogen. Therefore, the introduction of sea cucumber in the PS system also reduced the release of ammonia to the water from the sediment.

Sediment environment. This study showed that the feeding rate of the sea cucumber of sediments was about $0.06 \pm 0.02 \mathrm{~g} /\left(\mathrm{g}^{\cdot d}\right)$, which was slightly higher than that of others (Che, et al., 1990). The content of organic matter in the digestive tract of the sea cucumber was about four times that of the surrounding sediment and consistent with other findings (Klinger, et al., 1998; Dzeroski, et al., 2003; Yu, et al., 2011). In addition, sea cucumber assimilation rate of organic matter in the sediment was $40.26 \pm 10.62 \%$, and the addition of sea cucumber in PS system significantly reduced the organic matter and sulfide content in the sediment. The results above indicate that the sea cucumber is a regulator of the depositional environment in the shrimp-farming pond.

Growth and survival. The inorganic nitrogen in shrimp culture water was mainly in the form of nitrate, nitrite, and ammonia nitrogen. It was generally believed that nitrate has no toxic effect on shrimp. The toxicity came mainly from ammonia nitrogen and nitrite, and the ammonia nitrogen was highly toxic to shrimp (Qiu, et al., 2008). In this study, the concentration of ammonia nitrogen in each group increased with time, and was significantly higher than in the PS group and potentially more harmful to the shrimp. The toxicity to organisms of sulfides in the sediment were used by the sea cucumber in the PS group. The results showed that the addition of sea cucumber in PS system can effectively reduce the 
concentration of ammonia nitrogen and sulfide in the system and improve their survival rate.

In this study, the survival rate of sea cucumbers in PS groups was $100 \%$, and their growth rate was close to or higher than that of the sea cucumber in the co-cultured experiment with the shell (Zhou, et al., 2006; Slater, et al., 2007; Conand, et al., 1997). In addition, the results of respiratory experiments showed that the oxygen consumption rate of sea cucumber was very low (only 1/26 of the oxygen consumption rate of the shrimp) and at the same time the sea cucumbers have a strong ability to withstand hypoxia (Yu, et al., 2011).

\section{Acknowledgements}

This research was supported by the Special Scientific Research Funds for Central Non-profit Institutes, South China Sea Fisheries Research Institute, Chinese Academy of Fishery Sciences (2015TS10); Special Scientific Research Pilot Project of Sanya(2014KS03).

\section{References}

Asha P. S., Muthiah P., 2005. Effects of temperature, salinity and pH on larval growth, survival and development of the sea cucumber Holothuria spinifera Theel. Aquaculture 250: 823-829.

Battaglene S. C., Bell J. D., 1999. Potential of the tropical Indo-Pacific sea cucumber, Holothuria scabra, for stock enhancement. Bergen, Norway, Blackwell Science, Oxford: 478-490.

Bonham K., Held E. E.,1963. Ecological observations on the sea cucumbers Holothuria scabra and H. Leucospilota At Rongelap Atoll, Marshall Islands. Pacific Sci, 17(3): 305-314.

Bruckner A. W., 2005. The recent status of sea cucumber fisheries in the continental United States of America. SPC Beche-de-mer Inf Bull, 22:39-46.

Che R. G., 1990. Aspects of the feeding biology of Holothuria leucospilota Brandt (Echinodermata: Holothuroidea) in Hong Kong. Asian Mar Biol, 133-146.

Chen J., 2004. Present status and prospects of sea cucumber industry in China.FAO Advances in Sea Cucumber Aquaculture and Management Rome, pp. 25-38.

Conand C., 1986. Les resources halieutiques des pays insulaires du Pacifique. DeuxieÁme partie: Les holothuries. F.A.O.,Document Technique sur les PeÃches, 272.2 http://www.documentation.ird.fr/hor/fdi:010025823.

Conand C., Byrne M., 1993. A Review of Recent Developments in the World Sea Cucumber Fisheries. Mar Fish Rev, 55(4): 1-13.

Conand C., Morel C., Mussard R., 1997. A new study of asexual reproduction in holothurians: Fission in Holothuria leucospilota populations on Reunion Island in the Indian Ocean. SPC Beche-de-Mer Information Bulletin, 9:5-11.

Dong Y. W., Dong S. L., Tian X. L., Wang F., Zhang M. Z., 2006.Effects of diel temperature. fluctuations on growth, oxygen consumption and proximate body composition in the sea cucumber Apostichopus japonicus Selenka. Aquaculture, 255:514521.

Drumm D., Purvis M., Zhou Q. Q., 1999. Spatial ecology and artificial neural networks: modelling the habitat preference of the sea cucumber (Holothuria scabra) on Rarotonga, Cook Islands. 11th Annual Colloquium of the Spatial Information Research Centre, University of Otago, Dunedin, New Zealand, 1999.

Dzeroski S., Drumm D., 2003 Using regression trees to identify the habitat preference of the sea cucumber (Holothuria leucospilota) on Rarotonga, Cook Islands. Ecological Modelling, 170(2-3): 219-226.

He Z. P., Wang X. Y., Liu Y. F., Liu Y. H., Wang X., 2008. A High Efficiency Polyculture of Sea Cucumber Apostichopus japonicus with Kuruma Prawn Penaeus japonicus in Pond. Cell research Fisheries Science, 27(12): 665-667.

Hu C. Q., Xu Y. H., Wen J., Zhang L. P., Fan S. G., Su T., 2013. Spawning, larval development and juvenile growth of the sea cucumber Stichopus sp. (Curry fish). Aquaculture, 300(1-4): 73-79. 
Kang K. H., Kwon J. Y., Kim Y. M., 2003. A beneficial coculture: charm abalone Haliotis discus Hannai and sea cucumber Stichopus japonicus. Aquaculture,216(1-4): 87-93.

Klinger T. S., Johnson C. R., 1998 Spatial and temporal distribution of feeding of Aspidochirotida(Holothuroidea) on Heron Island, Great Barrier Reef. 9th International Echinoderms Conference, Balkema, Rotterdam, 467-471.

Liu H. D., Wang L., Wang B. J., 2008. Analysis on the diversity of microorganism in intestine of Penaeus vannamei-cultured by PCR-DGGE. Feed Industry,29(20): 55-58.

Liu S. L., Yang H. S., Zhou Y., Zhang T., Yuan X. T., 2006. Simulative studies on utilization efficiency of Apostichopus japonicus on the biodeposit in the raft culture system in shallow sea. Mar Sci. 30(12): 21-24.

Maxwell K. H., Gardner J. P., Heath P. L., 2009. The effect of diet on the energy budget of the brown sea cucumber, Stichopus mollis (Hutton). J World Aquacult Soc, 40(2): 157170.

Mercier A., Battaglene S.C., Hamel J. F., 2000.Settlement preferences and early migration of the tropical sea cucumber Holothuria scabra. J Exper Mar Biol Ecol, 249(1):89110.

Paltzat D. L., Pearce C. M., Bames P. A., McKinley R. S., 2008. Growth and production of California sea cucumbers (Parastichopus Californicus Stimpson) co-cultured with suspended Pacific oysters (Crassostrea gigas Thunberg). Aquaculture,275(1):124-137.

Purcell S. W., Patrois J., Fraisse N., 2006 Experimental evaluation of co-culture of juvenile sea cucumbers, Holothuria scabra (Jaeger), with juvenile blue shrimp, Litopenaeus stylirostris (Stimpson). Aquacult Res, 37(5):515-522.

Qiu D. Q., Zhou X. J., Qiu M. S., 2008. Study on anti-disease ability of Litopenaeus vannamel and the biological control of vibrio parahaemoltyicus bacteriophage under stresses of ammonia nitrogen. J Hydrobiol. 32(4):455-461.

Slater M. J., Carton A. G., 2007. Survivorship and growth of the sea cucumber Australostichopus (Stichopus) mollis (Hutton 1872) in polyculture trials with green-lipped mussel farms. Aquaculture, 272(14): 389-398.

Tang Y. Y., Tao P. Y., Tan J. G., Mu H. Z., Peng L., Yang D. D., Tong S. L., Chen L. M.,2014. Identification of bacterial community composition in freshwater aquaculture system farming of Litopenaeus vannamei reveals distinct temperature-driven patterns. Mol. Sci.,15(8):13663-13680.

Uthicke S., 2001. Interactions between sediment-feeders and microalgae on coral reefs: grazing losses versus production enhancement. Mar Ecol Progress Series, 210:125-138.

Uthicke S., 2001. Nutrient regeneration by abundant coral reef holothurians. J Exper Mar Biol Ecol, 265(2):153-170.

Wang R. J., Jiang L. X., Li J., 2007. The Toxic Effect of Ammonia Nitrogen and Sulfurated Hydrogen on the Larvae of Penaeus japonicus. Marine Science. 31(7):51-55.

Yang H. S., Wang J., Zhou Y., Zhang T., Wang P., He Y. C., Zhang F. S., 2000. Comparasion of effeciencies of different culture systems in the shallow sea along Yantai. $J$ Fish Sci. 24(2): 140-145.

Yu Z. H., Hu C. Q., Zhou Y., Li H. P., Peng P. F., 2011. Survival and growth of the sea cucumber Holothuria leucospilota Brandt: A comparison between suspended and bottom cultures in a subtropical fish farm during summer. Aquacult Res, 44(1):114-124.

Yu Z. H., Qi Z. H., Hu C. Q., Liu W. G., Huang H. H., 2012. Effects of salinity on ingestion, oxygen consumption and ammonium excretion rates of the sea cucumber Holothuria leucospilota. Aquacult Res, 44(11):1760-1767.

Yuan X. T., Yang H. S., Zhou Y., Mao Y. Z., XuQ., Wang L. L., 2008. Bioremediation potential of Apostichopus japonicus (Selenka) in coastal bivalve suspension aquaculture system. J App Ecol 19(4):866-872.

Zhou Y., Yang H. S., Liu S. L., Yuan X. T., Mao Y. Z., Liu Y., Xu X. L., Zhang F. S., 2006. Feeding and growth on bivalve biodeposits by the deposit feeder Stichopus japonicus Selenka(Echinodermata: Holothuroidea) co-cultured in lantern nets. Aquaculture, 256(1-4):510-520. 